\title{
KNOWLEDGE MANAGEMENT AND ORGANIZATIONAL PERFORMANCE OF SELECTED DEPOSIT MONEY BANKS IN NIGERIA
}

\author{
https://doi.org/10.47743/jopafl-2021-22-16
}

\author{
Festus OSAYANDE \\ University of Benin, \\ Benin City, Nigeria \\ osayandefestus56@gmail.com
}

\begin{abstract}
This study examined knowledge management and organizational performance of selected deposit money banks in Nigeria. Specifically it determines the relationship between them and hence the effect of knowledge acquisition, knowledge conversion, knowledge application and knowledge protection on the performance of deposit money banks in Nigeria. In pursuance of the above, the study employs the survey research design. Data was obtained from the employees of the five banks by simple random sampling technique method. Taro Yamane's formula was used to determine the sample size of 400 respondents. Proportionate representation was used to get the 400 respondents since the number of employees was not the same in each of the five banks. Data analyzed was subjected to simple percentage, descriptive statistics, and normality test. Correlation and OLS linear regression analysis was also carried out. The result revealed that knowledge acquisition practices have significant positive relationship on performance by deposit money banks in Nigeria, that knowledge conversion practices have significant positive relationship with performance of deposit money banks in Nigeria, that knowledge application practices have significant positive relationship with performance of deposit money banks in Nigeria and knowledge protection practices have significant positive relationship with performance of deposit money banks in Nigeria. The contributions to knowledge were that the study affirmed knowledge acquisition facilitates organizational performance through its increased marketing effort, that knowledge conversion enhances organizational performance by way of expertise and efficiency, that knowledge application helps in the area of better risk management and that knowledge protection enhances competitive advantage of the organization. The study demonstrated a hybrid of resourced based theory and left brain and right brain management theory. The study recommends among others that deposit money banks should encourage knowledge conversion practices so that their performance will improve.
\end{abstract}

\section{Introduction}

Knowledge management has assumed an important dimension in organizations today due to the fact that the major competitive advantage of these organizations lies on attracting and retaining corporate knowledge (Lee \& Choi, 2006). This invariably presupposes that for organizations to prosper, they have to treat knowledge well since it contributes to their core competencies, just as they would do to any other strategic, irreplaceable assets. Therefore, managing knowledge involves the leveraging of intellectual assets to enhance organizational performance (Stankosky, 2008, Ahmed \& Mohammed, 2017, Felix \& Guillermo, 2017, Hayfa \& Abdullah, 2018, Akram \& Hilman, 2018). Deposit money banks require urgently adequate knowledge management practice to be able to stand against competition in the marketing environment.

The goal of knowledge management is to ensure that organizations are aware of the knowledge at their disposal both individually and collectively. Deposit money banks need 
to find out their strengths, weaknesses, opportunities and threats available to them so as to operate profitably. This will help these organizations to make the most efficient and effective use of their knowledge for good result thereby enhancing performance. To this end, knowledge management remains one of the many strategies that successful organization seek to identify, select and organize so as to enhance employee performance and organizational competitiveness. This is why deposit money banks should key into this operational revolutionary strategy for success. Therefore, knowledge management is largely concerned with developing, depositing, extracting and sharing knowledge for subsequent retrieval which is needed to ensure smart decision for organizational growth and development (Bamgboje, Ayodele\& Ellis, 2015). According to Hislop (2013), knowledge management is an umbrella term which refers to any deliberate effort made to manage the knowledge of organizational workforce, which can be achieved via a wide range of methods including the direct use of Information Communication Technology (ICT) or more indirectly through the management of social processes, structuring of organization in a particular way or via the use of particular culture and people management practices.

If deposit money banks are able to do this, they can remain afloat always. In addition the perspectives of the author identified above explored, these banks will survive. Knowledge provides superior offerings which are given to customers by way of value. Value cannot be offered without some competencies by organizations. Competencies are brought about by organization's knowledge. Only employees in organizations can provide value to customers. This can only happen if they are motivated through training, workshops, seminars, career part development, short courses, medical care, company vehicles and the creation of a good work-life balance. When these are done their skills in work activities will go up. The knowledge in an organization gives a competitive advantage if properly managed by the organization. In a sense, competitive advantage is a single key element that gives an edge to a business beyond what the competitor has and does. Competitive advantage represents a threat to competitors and weakens them if readily available such that the holder can easily rely on it.

It should be noted that the growing important role of knowledge has motivated businesses to move from general management activities to knowledge management (Cho \& Korte, 2014; Tubigi \& Alshawi, 2015). Many organizations accept knowledge management as a paradigm shift and hence a new orientation. This perspective suggests that knowledge infrastructures (which are technology, structure, and culture) are vital for operations. Others include knowledge process architecture for the identification, acquisition, conversion, application, and protection of knowledge. Deposit money banks need to develop in technology, structure; a good organizational culture for in them laid organizational growth and development. They need to acquire, convert, apply and protect knowledge.

Knowledge management is concerned with the entire process of discovering and the creation of knowledge, dissemination of knowledge and the utilization of knowledge. Knowledge management principles recognize that it is important for organizations "to know what they know”. All businesses inherently store, access and deliver knowledge in some specific manners. Knowledge is required in other to enjoy an outstanding competitive advantage. Awan and Jabbar (2015) and (Akram \& Hilman, 2018; Onyango, 2018; Ahmad \& Mohamed, 2017) stated that proper knowledge management improves the performance 
of organizations whether it is public or private. They also emphasized that the retention and proper training of employees not only improve their skills but also build up confidence in them.

The creation of knowledge is essential for the survival of any organization. Knowledge is an activity that happens throughout daily work activities and this is required for their survival in a competitive market. These could be by formal training or talking with those who share similar interests or by technical mechanism such as data mining activities. Knowledge creation is primarily a human process where technology can facilitate knowledge creation but cannot replace people and hence their continuous development and improvement. Therefore, it is logical to conclude that the ability to create knowledge and generate a competitive advantage is essential for any organization that wishes to remain relevant and be able to achieve wider market share that is sustainable as this will in turn produce excellent performance.

Performance involves a complex series of actions that integrate skills and knowledge to produce valuable results. Examples include designing, selling, production, playing a sport and other activities involved in solving a problem. In some instances, the performer could be an individual, a collection of people who are collaborating such as an academic department, research team and student's team. Performance is a journey and not a destination. Different locations in the journey provides for different levels of performance. Each level defines the efficiency, quality and effectiveness of performance. Quality efficiency, effectiveness in performance cannot happen if employees are not developed and therefore becomes necessary that it takes its hold.

Organization's strategy of achieving excellent performance includes actions that engage positive emotions through employees. Examples of such are setting challenging goals and allowing failure as a natural part of attaining high performance. These banks can only have good results if they are doing the right things at the right time. Beyond that, there is the need to provide conditions in which the organization feels the right amount of safety. In all of this, health and safety at work should be the watch word. Armstrong (2006) defined performance as accumulated end results of the organization's works processes and activities. It is about how effectively an organization transforms inputs into outputs and comprises the actual outputs or results as measured against its intended outputs. According to Richard (2009), organizational performance covers three specific areas of the organization; financial performance, product market performance and shareholder return. Deposit money banks should recognize that they represent the financial sector of the economy. As such certain demands are required of them by the federal government and the central bank of Nigeria, the society and other shareholders which should not be ignored. Liptons (2005) proposed that the firm's performance is the ability of the firm to prevail under certain circumstance and be able to achieve positive results.

When organizational performance is excellent, deposit money banks quality increases and as a result, services become more effective in meeting or exceeding the expectations of customers. Cost decreases as the amount of effort or financial resources to produce result and waste goes down. Capability increases as the ability to tackle more challenging performances or projects would be on course. They need to generate more revenue at minimum cost to remain in business. In addition there is also the ability to generate more revenue for the organization. As the depth and breadth of knowledge increases, skills and abilities to set goals increases and these results in improved 
productivity as the increase in breadth and depth of application provide for effectiveness, identity and motivation of work activities. Individuals develop more sense of who they are as professionals in organizations to develop their essence. When productivity is high, the goal achievement is not far away. From the above, it is expected that knowledge management will be able to improve growth, innovation, productivity as efficiency is reflected in cost saving, customer relationships and decision making. Others will include corporate image building, development of new product line, employee learning, satisfaction and retention. When put together, this gives the organization a competitive advantage which results in outstanding performance.

In a vibrant economy, deposit money banks have a role to play and this makes it imperative for them to be involved in proper and focused knowledge management practices to improve the effectiveness of their operations. Although these banks have been in the forefront of business process re-engineering, there have been little evidence to indicate that they have institutionalize knowledge management practices towards organizational performance. This study examines knowledge management and organizational performance of selected deposit money banks in Nigeria.

\section{Statement of the Research Problem}

With the advancement in information and technology overtime, knowledge has become a vital resource for organizations to gain a competitive advantage and improve their performance. To this end, the major source of wealth and prosperity are in the production and distribution of information and knowledge by organizations for employees and businesses to thrive. However, it has been observed that the frequent upsurge in employers turnover in these banks has led to loss of knowledge sources and experiences of employees including the casualization of workers, outright retrenchment of permanent staff and being replaced with contract staff, sudden dismissals, restructuring, job transfer and other alternative work arrangements. Beyond that, management actions have often reflected in lack of system upgrade, lack of good work structure, complex restructuring, information decay, banks' ineptitude, lack of organizational commitment and poor security information. This position has made good quality service to dwindle and customers' switching these banks was not in doubt. The combination of these observations has provided an inn road for poor performance. At some point, organizations struggle with knowledge loss in their operations. This makes it necessary for all members in the organization to generate and share knowledge such that knowledge sharing becomes a personal issue that requires personal commitment. This will not only increase profit but also improve quality, quantity, innovations, efficiency, effectiveness and competitiveness. Therefore, there is need to assess the effect of knowledge management on the performance of deposit money banks in Nigeria and this study fills this need.

Besides, the majority of individuals that work in banks are knowledge workers (Ann, Ezeobi \& Human, 2015). When deposit money banks fail to improve the knowledge management process, they are hard hit if knowledgeable employees leave the organization suddenly. Before any damage is done, such organizations are advised to identify employees who have relevant knowledge and be able to tap, store and retrieve this knowledge for use profitably. Deposit money banks that are successful today are also aware of the importance of managing knowledge and therefore develop plans on how to accomplish goals and 
devote time and energy for the achievement of results. In addition, KM as a growing area, the fact exists that few research works have been done in the Nigerian banking sector made available in(Nnabuife, Onwuka \& Ojukwu, 2015; Edwinah, 2014; Ugurlu, 2013).This is where the research hinged on to examine knowledge management and organizational performance of deposit money banks in Nigeria.

The research gap identified in the study has to do with content and scope. In content, the variables of knowledge could not fully address all of the situations analyzed. There were only one or two components of knowledge which then could not be generalized in the study. In scope, most of the studies were done in developed countries in which the variables used could not be the same like Nigeria - a developing country. Hence, the points identified only highlighted four major components of knowledge.

\section{Objectives of the Study}

The broad objective of this study is to examine the relationship between knowledge management and organizational performance in the banking sector of Nigeria. The specific objectives are to:

- determine the effect of knowledge acquisition on the organizational performance of deposit money banks in Nigeria;

- examine the relationship between knowledge conversion and the organizational performance of deposit money banks in Nigeria;

- $\quad$ ascertain the effect of knowledge application on the organizational performance of deposit money banks in Nigeria and to

- $\quad$ examine the influence of knowledge protection on the organizational performance of deposit money banks in Nigeria.

\section{Hypotheses of the Study}

The following performance hypotheses stated in the null form were formulated to guide this study:

H1: Knowledge acquisition does not have significant effects on the organizational performance of deposit money banks in Nigeria.

H2: There is no significant relationship between knowledge conversion and the organizational performance of deposit money banks in Nigeria.

H3: There is no significant relationship between knowledge application and the organizational performance of deposit money banks in Nigeria.

H4: There is no significant relationship between knowledge protection and organizational performance of deposit money banks in Nigeria.

\section{Scope of the study}

The study examined the effect of knowledge management on organizational performance of deposit money banks in Nigeria. It covered selected deposit money banks in Nigeria. This became necessary because of the importance of this sector to the economy of the country. The sector is very fragile and therefore very sensitive to any economic, financial and labour crisis. It was also observed that this sector is very important as it contributes maximally to the growth and development of the Nigerian economy especially through the process of financial intermediation. The financial sector required some attention because of the need to strengthen their operations. Overtime these had been 
frequent labour turnover through termination of appointment and voluntary resignations by bank employees. For the purpose of this study, five of the sixteen banks in the country also quoted at the Nigerian stock exchange were examined as a population. The time frame was three weeks to distribute and retrieve questionnaire covering knowledge acquisition, knowledge conversion, knowledge application and knowledge protection question items as variables for investigation.

\section{Significance of the Study}

The findings of this work will assist the following parties.

Deposit money banks - strategic managers in the banking sector would be adequately informed of the experiences of customers with bank employees, with the aim of providing quality service to them. This will in effect improve performance.

Banking organizations- policy makers and other sectors could now learn more on how to apply knowledge management towards the enhancement of their performance in business operations. The learning outcome could go a long way to revive the banks toward better results.

Entrepreneurs- it would be as a self assessment tool on the level of adoption of knowledge management practices to push through the performance of organization positively. For this work, employees are to be informed about the value of knowledge management.

Financial institutions - The skills available could be shared such that the acquired information will provide a guide on the need to sharpen their operations in dealing with challenges in knowledge management related issues.

Professional bodies -The Nigerian Institute of Management (Chartered) and the National Institute of Marketing of Nigeria (Chartered) in understanding the sector, a memorandum of understanding (MOU) will be created to enable them review codes of Ethics in the banking sector should the need arise.

Academics - The outcome of this work could also form the basis for further studies by researchers as they may seek to replicate the study to test its result or to expand the frontier by including other variables. The study could also add to the body of knowledge management on how to assess the determinants that affect organizational performance in Nigeria.

Bank management - The study would have important implications for the banks by figuring out positive outcomes in their operations regarding performance majorly. To this end, Nigerian banks will move to a new level of re-engineering from recapitalizing and restructuring dimensions of the 1990s. Business operators will identify the urgent need on re-enforcing the essence of knowledge management as a demand call in the running of businesses today and always.

The expectation is that this study will contribute to the body of literature on knowledge management in Nigeria and hopefully encourage further research into how to deepen knowledge management in the banking sector. It will also help to awaken organizations in Nigeria and elsewhere to see the potentials of knowledge management, thereby spurring them up to invest in its execution as a business strategy to enhance their performance.

\section{Conceptual Framework}

Concept of Knowledge Management 
According to Odiri (2014), knowledge is the insight, understanding and practical know-how that we all possess. It is the fundamental resource that allows us to function intelligently. From the above definitions, it is clear that knowledge is an invisible or intangible asset. Its acquisition involves complex cognitive processes of perception, learning, communication, association and reasoning (Akinyemi, 2007).

Over the years, knowledge has been stored in traditional ways: such as oral traditions, clay tablets, scrolls, books and manuals. To a very large extent today managers in organizations now use the know-how of people they have hired, with skill and experience processes for effective management. The loss of intellectual assets due to downsizing of organization's workforce has resulted to a decrease in productivity, teamwork, innovation and talent. These trends can only be reversed if organizations are able to explore ways of capturing and managing knowledge of their employees effectively for result. This means that implementing an efficient knowledge practice allows for competitive advantage edge. Others will be reduction in intellectual capital, lowering costs and a decrease in redundancy in knowledge based activities.

As a discipline, knowledge management encourages organizations to focus on determining its knowledge to explain it, so that it can be shared formally for its reuse. By definition, knowledge management is a process that helps organizations find, select, organize, disseminate and transfer important information and expertise required for activities for problem solving, dynamic learning, strategic planning and decision making (Gupta, lyer \& Aronson, 1996). Even though knowledge management is dependent primarily on organization culture (due to its being shared), motivation, and policies, it requires the right technologies for its implementation to reach the goal of the firm. The creation of knowledge depends largely on the data base, active process management, knowledge centers, collaborative technologies and knowledge websites.

\section{Empirical Review}

Valmohammadi and Ahmadi (2015) examined the impact of knowledge management practices on organizational performance. They presented a holistic approach regarding evaluation of knowledge management practices on organizational performance in the framework of four perspectives of balanced Scorecard (BSC). Research findings revealed that KM activities positively and meaningfully impact on overall organizational performance. Nnabufe, Onwuka and Ojukwu (2015) carried out a study on selected commercial banks in Awka, Anambra State, Nigeria on knowledge management and organizational performance. 35 respondents were involved; pearson's product moment correlation coefficient was used to analyze the data generated. The findings revealed that knowledge identification attributes to organizational performance and that knowledge acquisition has a significant effect on organizational performance. Akpotu and Lebari (2014) examined the relationship between knowledge acquisition practices and performance of administrative employees in educational institutions in South-South Nigeria. The findings revealed a significant relationship between knowledge acquisition and administrative employees’ performance. Popov and Vlasov (2014) studied knowledge generation at universities in Kuwait and compared research output of universities with transaction costs. The study results revealed that transaction cost determines research performance in terms of published research and obtaining patents. Others are participation 
in conference and exhibitions which are directly proportional to the number of economic units established at the universities for promoting the application of research achievements.

Romano (2014) studied knowledge creation and exploitation in Italian universities and the factors that affect academic patent activities. The study showed that this activity is mainly influenced by the internal policies of the universities and this is seen by academics as a signal of the university inclination and attempt to develop an environment conducive to patent activities and to offer structured support to inventors in the different phases of the patenting process. Chweya, Ochieng and Riwo-Abudho (2014) did a study in Kenya to determine the extent of knowledge creation, knowledge sharing and knowledge acquisition practical in commercial banks in Kisumu City. Correlation analysis showed that over 45\% of the respondents' approved effective staff development tools to support management practices. Less than 13\% respondent said no, 65\% agreed that their banks had formal mechanism in place which guaranteed the sharing of best practices in work activities. Odiri (2014) study on knowledge management and organizational performance in selected oil companies in Nigeria showed that tacit knowledge actually predicts organizational performance. The study further showed that motivational incentives and participative leadership contribute negatively to the relationship of tacit knowledge and organizational performance while workers competence, interpersonal relationship and organizational philosophy contribute positively to the relationship of tacit knowledge and organizational performance. Ahmad, Mohamad and Ibrahim (2013) employed a survey method in finding out the relationship between individual's absorptive capacity and knowledge acquisition behaviors by engineers in electrical and electronic sector in Malaysia. There were 305 responses for the survey. Partial least square (PLS) properties of structural equation model (SEM) were used to measure the relationship between variables. They found out that individual absorptive capacity has partial influence on employees' knowledge acquisition.

Mahammad, Mehhred, Salma and Nurizy (2013) investigated the influence of knowledge management practices on organizational performance in small and medium scale enterprises in Iran. Structural Equation model (SEM) was used. In it senior managers from these enterprises were chosen using simple random sampling technique for the sample size. The findings showed knowledge acquisition, storage creation and implementation of knowledge have a significant factor on knowledge management. He concluded that productivity and financial performance, staff performance, innovation, work relationships and customer satisfaction have significant relationship on organizational performance. The results suggest that knowledge management activities directly influence the organizations (SMEs). The study cannot be generalized to a developing country like Nigeria. Also, the knowledge acquisition was the only variable used; hence its findings may be limited. Alnaweigah (2013) discussed the impact of KM functions on the organizational excellence from the perspective of the University of Al-Taif Staff, Kuwait. The study assessed the reality of KM at the university and explored its impact on increasing excellence of its employees. The study findings showed a statistically significant impact of KM dimensions on organizational excellence among the staff of the university and a statistically significant difference in their evaluation of the level of KM which can be attributed to their functional and demographic characteristics. Adbsel, Gawater and Mohamad (2012) investigated the role of knowledge management in enhancing organization performance. Some Egyptian organizations formed the population. Questionnaire was used to collect the required information. The result showed that all elements of knowledge management capabilities 
have a positive significant relationship with all measures of the performance at $1 \%$ level of significance. This means there is a great correlation between knowledge management capabilities and organizational performance. William, John and Peter (2012) carried out a research trying to fill the gap surrounding a particular knowledge management process called knowledge identification. The paper reports the findings of a survey sent to 973 Australian organizations to investigate identification practices. The survey findings showed that while organizations do perceive identification to be important, the practice of identification has not reached mainstream adoption yet. The survey findings also reveal two opposing approaches. Organizations take in practicing knowledge identification; proactive knowledge identification and reactive knowledge identification. Martin (2012) examined the knowledge acquisition strategies and company performance of Young high Technology company in Germany. The uses of quantitative and qualitative data were employed. The study revealed four discrete knowledge acquisition strategies. (Low-key, mid-range, focus and explorer) and showed that strategies differ in their relation to company performance. This was as a result of their configuration of knowledge acquisition activities and the type of knowledge acquired. Rasula and Stemberger (2012) studied Slovenia and Croatia companies to show that organizations can enhance organizational performance through creating accumulating, organizing and utilizing knowledge. The study showed empirically that information technology, organization and knowledge positively affect organizational performance. Emadzade, Mashayekhi and Abdar (2012) examined the impact of specific KM dimensions on organizational performance of 245 small size business owners and managers at a managerial level in their firms from (86) enterprises in Isfahan. The study results showed that some knowledge resources are directly related to organizational performance while others are not. Mills and Smith (2011) evaluated the impact of specific knowledge resources on organizational performance using survey data from (189) managers using structural equation modeling. The study showed that some knowledge resources are directly related to organizational performances while others though important pre-conditions for knowledge management are not directly related.

Research carried out by Tan and Narsurdin (2011) showed that Human Resources Management (HRM) practices (performance appraisal, career management, training and reward system recruitment) have a positive effect on organizational innovation. Their findings indicated that training was positively related to three dimensions of organizational innovation that is product innovations, process innovation and administrative innovation. Performance appraisal was also found to have a positive effect on administrative innovation. Additionally, their findings also showed that training and performance appraisals are positively related to knowledge management effectiveness. Alzoubi and Alnajjar (2010) studied KM architecture of Jordanian universities. He tested a set of variables relating to knowledge management. The study revealed that the pillars of KM architecture consist of strategy and commitment, information systems, culture and communications. Research by Moffet and Hinds (2010) revealed that successful knowledge management implementation emancipates employees. Knowledge workers have flexibility and freedom to conduct their work according to their own intelligence, experience and initiative. They support each other as well as by technology and information infrastructure which resultantly benefit both themselves and the organization. Stefanescus and Stefanescus (2008) discussed the factors that motivate in sharing knowledge before implementing any KM strategy to sustain the successful implementation of reengineering 
projects. The study concluded that in order to achieve success with reengineering projects, organizations should possess and share knowledge about many different facets of this process. The improvement of performance of re-engineering projects comes because of coupling IT capabilities with KM strategy.

Ababneh (2008) examined the impact of knowledge management and organizational learning on organizational innovation. The study showed a strong positive correlation between knowledge, management, organizational learning and organizational innovation and that demographic variables have a significant impact on practicing each dimension while educational level and departmental size have no significant impact. Basu and Sengupta (2008) assessed success factors for learning in business schools in India. Study results showed that many successful KM initiatives were taken by business schools. These were both expensive and propositions. Sujatha (2007) explored critical success factors for implementing KM. The study highlighted barriers and challenges that face KM efforts and showed that organizations have knowledge distributed across people, technologies and organizational activities. And that they can acquire new knowledge that will enable them to stay competitive in the market place. Siretea and Grigonita (2007) examined perspective of knowledge management in Jordanian universities. The study revealed that universities can accomplish their missions as learning organizations through $\mathrm{KM}$, aiming to acquire knowledge used to improve organizational performance with an accent of improving efficiency, effectiveness and innovation. From the research carried out by Hoegi and Schulze (2005), the results obtained were that companies that used knowledge management methods in the creation of New Product Development have accrued a lot of benefits. For instance, employees at British Petroleum (BP) Amoco used experience workshop which is one of the knowledge management methods. With this method, employees gather a vast amount of experience and tacit knowledge which comprises both technical knowledge and personal knowledge about relationship and team structure. Maponya (2004) highlighted knowledge management in academic libraries in South Africa. The study found that the role of academic libraries is changing to provide a competitive advantage for the parent universities and their success depends on their ability to utilize information and knowledge of its staff to better serve the needs of the academic community.

\section{Brief History and Development Deposit Money Banking in Nigeria}

The banking in Nigeria could be traced to the period between 1892 and 1894. It was at that time that African Corporation and First Bank of Nigeria formerly known as the Bank of British West Africa (BBWA) were established in 1894. The colonial banks came into Nigeria at the time. Their presence affected financial activities including their influence on trade and other commercial transactions throughout West Africa. Backlays Bank for example entered into financial operations in Nigeria around 1925.

By way of reforms after many years in the system, the British government in 1952 received a report from Mr. Paton G. D. of the bank of England from the inquiry instituted by government and on the extent of control to be introduced as the banking sector. The outcome of the inquiry provided the platform for the first banking ordinance in 1952. The ordinance was to ensure the orderliness in commercial banking and to prevent the establishment of unviable banks and unregulated banking transactions. Between 1959 and 
1989 there was deregulation. The financial and banking sector was technically in place through the creation of Structural Adjustment Programme (SAP). It was inspired by the Breton Wood's conference.

In order to safeguard the depositors' money, in 1988, the government established the Nigeria Deposit Insurance Corporation (NDIC). It was charged with the responsibility of carrying out some sort of financial reforms and assisting the Central Bank of Nigeria in formulating policies in the areas of ensuring safe and banking services and supervisory role with the Central Bank that the NDIC act was aimed at.

\section{Supervisory Mechanisms in Nigerian Banks and their Roles}

The Nigeria Banking sector is primarily regulated by two bodies. The first is the Central Bank of Nigeria (CBN) which has the superior regulatory power. It was established by the Central Bank of Nigeria Act of 1958. It commenced operations on 1st July, 1959. As one of its primary functions, the bank promotes monetary stability and ensures a sound financial system, and acts as banker and financial adviser to the Federal Government. It is the banker of the last resort to commercial banks. It encourages the growth and development of financial institutions. It has a feasible role in the areas of policies formulation, establishment of specific administrative or bureaucratic procedures which must be adhered to by all banks and financial institutions in Nigeria.

The Nigeria Deposit Insurance Corporation (NDIC).

The NDIC compliments the regulatory and supervisory role of the CBN. It is autonomous of the CBN but reports to the Federal Ministry of Finance. The NDIC is responsible for insuring financial institutions, paying and controlling deposits in accordance with its mandate in the event of bank failure of an insured financial institution. It is empowered to examine the banks' books and affairs of insured banks and other deposit-taking financial institutions. By this arrangement, licensed banks are mandated to pay $15 / 16$ of $1 \%$ of their total deposit liabilities as insurance premium to the NDIC. As a result, a depositor's claim is certified to a maximum of N50,000 in the event of a bank failure. It helps to protect depositors and their deposits.

Three ways by which NDIC supervises the banking system

- Transaction-based supervision

- Risk-based supervision

- Consolidated supervision

You also have external auditors often drawn from private companies. They provide periodic audits of the financial books and records of the banks. In order to strengthen the banking sector there is the corporate governance policy in Nigeria located at the Central Bank of Nigeria. This is called the Bank code of governance. It deals mainly with ethics and efficiency in services rendered by the regulated banks. To this end in 2009 the CBN's hammer fell on eight banks and their CEOs were removed and their directors were scrutinized, to ensure sanity in the system. Interest rate has been a major concern to CBN, as it slows down the ability to borrow from banks. There are challenges facing regulations in Nigeria. These regulations are anti-developmental and against the good conduct of business in the country. This results to inefficiencies, inadequacies and bureaucratic confusion in the Nation's banking sector. This situation has resulted to deficit financing, total confusion, reckless fiscal guidelines operations and unrealized objectives. The CBN 
is seen as being controlled by the federal ministry of finance as proposals are sent to it on monetary policies for scrutiny and assessment by the ministry. From this standpoint, it becomes obvious that politics is reflected in policies under the guise of state intervention as a method of economic control.

Eclecticism as a political concept has affected the foundation of regulation and other supervisory laws of the CBN. In it, there is the notion that certain group of people be favored and treated and that as a result of perceived superiority in terms of intellect, social status or financial resource, they deserve to be honored. This becomes obvious when state intervention is being used as an instrument of economic regulation. For example the selection of the governor of the Central Bank is more of political issue than qualification, though there could be some qualification components. As politics, wealth, power, position and status are not permanent, changes are provided in administration and personnel to make a difference in ways things should be done by providing rules and policies differently to do government business.

In the sector therefore continuity is not sustained. This position gives rise to internal politics, confusion based bureaucracy and bottlenecks are at play. Beyond that is the compulsory submission of proposals by the central Bank of Nigeria on monetary policies and other fiscal matters to the federal ministry of finance for security and assessment at the end of each year. The outcome of this is that the CBN is constrained to make policies which may be either politically motivated or at variance with the tenets of adequate and effective banking supervisory policies as a matter of national policy. The frequent change in the top management has also created inconsistencies in its laws and its regulatory framework. For example, in the year 2000 the universal banking guidelines came up. The CBN Authorized banks to engage in non-core banking financial activities, either directly as part of banking operations, or through designated subsidiaries but nine years later this was repealed by the power conferred on the CBN governor. To this end, there was the downplay of facts relating to the influence of political groups on financial and monetary policies, the Nigerian Banking policies, laws and regulation are not in doubt. This position is supported by the leading lawyer and economic scholar Richard Posner who submitted that "Ultimate premises of law are political” and the Nigerian financial laws, regulatory policies and supervisory structures reflect this position.

\section{Research Gap}

The gap identified in the study has to do with content and scope. In content, the variables of knowledge could not fully address all of the situations analyzed. There were only one or two components of knowledge which then could not be generalized in the study. In scope, most of the studies were done in developed countries in which the variables used could not be the same like Nigeria - a developing country. Hence, the points identified only highlighted four major components of knowledge.

\section{Methodology}

\section{Research Design}

Survey research design was used to conduct this research. Specifically, we adopted the cross sectional survey research design due to the large number of respondents who participated through questionnaire administration within a particular period of time and where evidence was evaluated and hypotheses generated. Because it was a survey, the 
researcher distributed the questionnaire (structured form) to respondents to ensure the collection of data and to make appropriate conclusions after analysis.

\section{Population, Sample Size and Sampling Technique}

The population of the study was 70,371 employees in the sixteen (16) listed banks on the Nigerian Stock Exchange as at March, 2019. From this population five banks were selected by simple random sampling technique method to determine the sample size from the five (5) banks selected namely; Eco-bank, (19142), First Bank (7616), Access bank (3192), Diamond bank (4731) and Polaris bank ltd (2804) constituted the sample banks of this study with a total of 37485 employees (Annual Account of Sampled banks, 2019). The employees were selected from senior management and staff of each bank to give a total sample size of 400 participants by proportionate representation. The unit of analysis was the number of employees as respondents from the five (5) selected banks as indicated above.

\section{Reasons for the Choice}

- The banks represent five of the biggest banks in total assets of the deposit money banks.

- $\quad$ They are quoted at the stock exchange

- They represent one-third of the sixteen quoted deposit money banks which in the opinion of the researcher was adequate.

- They formed a fair representation of the quoted banks.

The sample size of the study was obtained by using the Taro Yamane formula, stated thus

$$
n=\frac{N}{1+N e^{2}}
$$

$$
\begin{aligned}
& \text { Where } \mathrm{n} \quad=\quad \text { sample size } \\
& \mathrm{N}=\text { Population } \\
& \text { e } \quad=\quad \text { Level of significance (5\% i.e. } 0.05) \\
& n=\frac{37485}{1+37485(0.05)^{2}}=\frac{37485}{1+37485(0.0025)} \\
& =93.7125 \\
& =\frac{37485}{93.7125}=400
\end{aligned}
$$

\section{Sample Size $=\quad 400$ respondents}

The employees were selected from senior management and staff of each bank to give a total sample size of four hundred participants for the questionnaire administration by proportionate representation of the five banks in the following order.

Eco bank $\frac{19142}{37485} \times \frac{400}{1}=204$ respondents

First bank $\frac{7616}{37485} \times \frac{400}{1}=81$ respondents

Access bank $\frac{3192}{37485} \times \frac{400}{1}=34$ respondents

Diamond bank $\frac{4731}{37485} \times \frac{400}{1}=51$ respondents 
Polaris bank Ltd $\frac{2804}{37485} \times \frac{400}{1}=30$ respondents

Total $=400$ respondents

\section{Sampling Technique}

Questionnaire was administered to the respondents to generate the primary data needed for analysis. The questionnaire contained structured questions placed on the modified Likert five point scales. The responses scoring weights were strongly agree 5 points, agree 4 points, strongly disagree 3 points, and disagree 2 point, undecided 1 point.

\section{Model Specification}

The functional relationship of the dependent and independent variables is expressed as:

$$
\begin{aligned}
& \text { OGPEF }=f(K M) \\
& O G P E F=\alpha_{1}+b_{1} K A C Q N+e_{i} \\
& O G P E F=\alpha_{2}+b_{2} K C O N V+e_{i} \\
& \text { OGPEF }=\alpha_{3}+b_{3} K A P P L+e_{i} \\
& \text { OGPEF }=\alpha_{4}+b_{4} K P R O T+e_{i}
\end{aligned}
$$

Where KM is proxies by KACQN, KCONV, KAPPL and KPROT

$b_{1}>0$, An increase in knowledge acquisition would lead to an increase in organizational performance.

$b_{2}>0$, An increase in knowledge conversion would lead to an increase in organizational performance

$b_{3}>0$, An increase in knowledge application would lead to an increase in organizational performance.

$b_{4}>0$, An increase in knowledge protection would lead to an increase in organizational performance

\section{Validity Test of the Instrument}

The instrument was validated through face and content validity. To ensure this, all questions items were given to my supervisors and other experts in the field of management discipline for their observations and corrections. Also, copies of the questionnaire was given to management consultants to vet and advised respectively. This was to ensure the validity of the instrument, to ensure the relevance of the research questions set up in chapter one.

\section{Reliability Test of the Instrument}

To ensure the reliability of the instrument, a pilot study was conducted. A total of 46 copies of the questionnaire were used. They were distributed to the employees as respondents of the five (5) selected banks by simple random sampling method. These banks were Guarantee Trust Bank (3711), First City Monument Bank (2000), Zenith Bank (6275), UBA Bank (7427), and Sterling Bank (2243) with a total of 21656 as population which was outside the population where the sample size was determined above. Proportionate representation was used to determine the 46 copies distributed. 
Guarantee Trust $\frac{3711}{21656} \times \frac{46}{1}=8$

First City Monument $\frac{2000}{21656} \times \frac{46}{1}=4$

Zenith Bank $\frac{6275}{21656} \times \frac{46}{1}=13$

United Bank for Africa (UBA) $\frac{7427}{21656} \times \frac{46}{1}=16$

Sterling Bank $\frac{2243}{21656} \times \frac{46}{1}=5$

Total $=46$

The 46 copies of the questionnaire were administered, collected and analyzed which were not part of sample size but from the population of 21656. This was also suggested to Cronbach Alpha test and mean value of 0.79 was obtained which demonstrated the reliability of the instrument as indicated below

Table 1 Reliability Test

\begin{tabular}{|l|l|l|}
\hline Constructs & No of Items & Cronbach's Alpha \\
\hline Knowledge Acquisition & 7 & 0.793 \\
\hline Knowledge Conversion & 7 & 0.812 \\
\hline Knowledge Application & 7 & 0.811 \\
\hline Knowledge Protection & 7 & 0.712 \\
\hline Organizational Performance & 7 & 0.823 \\
\hline Mean & & 0.79 \\
\hline
\end{tabular}

Source: Stat. version (13) output, 2019

\section{Method of Data Analysis}

Percentages, mean, correlation and OLS regression techniques were used to analyze the data generated. All tests were carried out at $5 \%$ level of significance and the analytical tool used was STATA Version 13.0 to examine the relationships.

\section{Data Presentation, Analysis and Discussion of Results}

The data presented and analyzed in the study includes: first the descriptive analysis of respondents profile. The second is the correlation, regression analysis and then the testing of hypotheses formulated for the study.The questionnaire response rate was $300 / 400 \times 100 / 1=75 \%$

Table 2 Demographic Profile of Respondents

\begin{tabular}{|c|c|c|}
\hline Options & Frequency & Percentage \\
\hline Sex & & 89 \\
Male & 267 & 11 \\
Female & 33 & 100 \\
Total & 300 & \\
\hline
\end{tabular}




\begin{tabular}{|c|c|c|}
\hline Age & & \\
Bellow 30 years & 18 & 6 \\
30-40 years & 120 & 40 \\
41-50 years & 150 & 50 \\
Above 50years & 12 & 4 \\
Total & 300 & 100 \\
\hline Marital Status & 241 & \\
Married & 53 & 80.3 \\
Single & 2 & 17.7 \\
Widow & 4 & 0.7 \\
Divorced & 300 & 1.3 \\
Total & & 100 \\
\hline Highest Educational Qualification & - & \\
WAEC/GCE/NECO & 33 & - \\
OND/NCE & 85 & 11 \\
HND/B.Sc. & 175 & 28.3 \\
MBA/M.Sc. & 3 & 58.4 \\
Ph.D. & 4 & 1 \\
Others & 300 & 1.3 \\
Total & & 100 \\
\hline Years of Experience & 20 & \\
Below 11 years & 101 & 6.7 \\
11-15 years & 112 & 33.7 \\
16-20 years & 61 & 37.3 \\
21-25 years & 6 & 20.3 \\
Above 26 years & 300 & 2 \\
Total & & 100 \\
\hline
\end{tabular}

Source: Field Survey, 2019

Four hundred (400) copies of the validated questionnaire were administered. Three hundred and nine (309) copies were returned, nine copies of the questionnaire were rendered void therefore not usable because of unanswered questions, while three hundred (300) copies of questionnaire (75\%) used for analysis in the study. From the result of demographic profile of respondents in Table 4.1, it was observed that the respondents were made up of 267 males, representing 89\% of total responses, while 33 respondents are female, representing $11 \%$ of total responses. The age distribution of respondents shows that 18 respondents representing $6 \%$ are below the ages of 30,120 respondents representing $40 \%$ are within the ages bracket of 30-40 years, 150 respondents representing $50 \%$ are within the ages of 41-50 years, while 12 respondents representing $4 \%$ are above 50 years of age, implying the dominance of middle age workers in the service sector. 241 respondents representing $80.3 \%$ are married, 53 representing $17.7 \%$ of the total respondents are not married. This is in alignment with the age distribution of the employees, with $94 \%$ of the respondents above the age of 30 years.

On highest educational qualification of respondents, none had WAEC/GCE/NECO as their highest qualification, 33 respondents representing 11\% had OND/NCE, 85 respondents representing 28.3 had HND/BSC, 175 respondents representing $58.4 \%$ had MBA/M.Sc. as their highest qualifications, and only 3 respondents representing $1 \%$ had Ph.D. while 4 respondents representing $1.3 \%$ had other. Qualifications aside the ones mention. This indicates that the highest number of respondents sampled has MBA/M.Sc. 
qualifications. With respect to the years of experience, 20 of the respondents representing $6.7 \%$ has work below 11 years, 101 of the respondents representing 33.7\% has worked between 11-15 years, 112 representing 17.3\% has worked between 16-20 years, 61 respondent representing 20.3\% has worked between 21-25 years. While, 6 respondents representing $2 \%$ has worked above 26 years. Thus we can say that the respondents sampled are experience workers.

\section{Analysis of Data}

This section is concerned with analyzing the primary data sourced from the field survey in order to report the pattern of responses using simple percentage, correlation to examine the relationship that existed among variables and regression analysis to test the formulated hypotheses.

Table 3 Knowledge Acquisition

\begin{tabular}{|c|c|c|c|c|c|c|c|c|c|c|c|}
\hline S/N & Questionnaire Items & \multicolumn{2}{|c|}{$\mathrm{U}(1)$} & \multicolumn{2}{|c|}{ SD (2) } & \multicolumn{2}{c|}{ D (3) } & \multicolumn{2}{c|}{ A (4) } & SA (5) \\
\hline 1 & $\begin{array}{c}\text { There is need to obtain new } \\
\text { knowledge for my } \\
\text { organizations }\end{array}$ & - & - & 29 & 9.7 & 39 & 13 & 144 & 48 & 88 & 29.3 \\
\hline 2 & $\begin{array}{c}\text { There is reliance on } \\
\text { experiences, skills and } \\
\text { knowledge in my } \\
\text { organization }\end{array}$ & 26 & 8.7 & 48 & 16 & 41 & 13.6 & 39 & 13 & 146 & 48.7 \\
\hline 3 & $\begin{array}{c}\text { There is need for new } \\
\text { knowledge from external } \\
\text { sources }\end{array}$ & 10 & 3.3 & 27 & 9 & 19 & 6.3 & 155 & 51.7 & 89 & 29.7 \\
\hline 4 & $\begin{array}{c}\text { Knowledge is shared } \\
\text { through formal procedures }\end{array}$ & 20 & 6.7 & 20 & 6.7 & 49 & 16.3 & 117 & 39 & 94 & 31.3 \\
\hline 5 & $\begin{array}{c}\text { Organizational members } \\
\text { share knowledge orally at } \\
\text { formal or informal meetings }\end{array}$ & - & - & 9 & 3 & 29 & 9.7 & 174 & 58 & 88 & 29.3 \\
\hline
\end{tabular}

Source: Analysis of Field Survey, 2019

The descriptive pattern of response in Table 4.2 for knowledge acquisition subscale indicated that on the first questionnaire item, 232 (77.3\%) of the respondents strongly disagree to the construct (There is need to obtain new knowledge for my organizations and $68(22.7 \%)$ disagree. On the second item, 185 (61.7\%) respondent disagree that There is reliance on experiences, skills and knowledge in my organization, 89 (29.6\%) disagree and 26 (8.7\%) were undecided. On the third item sub-scale, 244 (81.4\%) respondents agree that There is need for new knowledge from external sources, 46 (15.3\%) disagree, while $10(3.3 \%)$ of the total sample respondents undecided. On the fourth construct in the subscale, 211 (70.3\%) agree that knowledge is shared through formal procedures, 19 (2.3\%), while 20 (6.7) where undecided. With regards to the fifth question, 262 (87.3\%) of the respondents agree that organizational members share knowledge orally at formal or informal meetings, 29 (9.7) disagree to the question. 235 (78.4\%) of the respondents disagree. 59 (19.7\%) disagree while 6 (2\%) were undecided about the question that Performance management is used as a measure for efficiency in an organization. 
Table 4 Knowledge Conversion

\begin{tabular}{|l|l|l|l|l|l|l|l|l|l|l|l|}
\hline S/N & Questionnaire Items & U (1) & \multicolumn{2}{l|}{ SD (2) } & D (3) & \multicolumn{2}{l|}{ A (4) } & \multicolumn{2}{l|}{ SA (5) } \\
\hline & & No & $\%$ & No & $\%$ & No & $\%$ & No & $\%$ & No & $\%$ \\
\hline 1 & $\begin{array}{l}\text { Ability to convert } \\
\text { knowledge into the design } \\
\text { of new product/service }\end{array}$ & 10 & 3.3 & 27 & 9 & 19 & 6.3 & 155 & 51.7 & 89 & 29.7 \\
\hline 2 & $\begin{array}{l}\text { Organizational knowledge } \\
\text { can be transferred to } \\
\text { employees }\end{array}$ & - & - & 28 & 9.3 & 40 & 13.4 & 88 & 29.3 & 144 & 48 \\
\hline 3 & $\begin{array}{l}\text { Knowledge from business } \\
\text { partners can be brought into } \\
\text { the organization }\end{array}$ & 25 & 8.3 & 49 & 16.3 & 41 & 13.6 & 39 & 13 & 146 & 48.7 \\
\hline 4 & $\begin{array}{l}\text { Conversion of knowledge } \\
\text { increases productivity }\end{array}$ & 27 & 9 & 10 & 3.3 & 10 & 3.3 & 164 & 54.7 & 89 & 29.7 \\
\hline 5 & $\begin{array}{l}\text { Knowledge conversion } \\
\text { reduces redundancy }\end{array}$ & 20 & 6.7 & 20 & 6.7 & 49 & 16.3 & 117 & 39 & 94 & 31.3 \\
\hline
\end{tabular}

Source: Analysis of Field Survey, 2019

The descriptive pattern of response in Table 4.3 for knowledge conversion subscale indicated that on the first questionnaire item, 244 (81.4\%) of the respondents agree to the construct that their organization has the ability to convert knowledge into the design of new product/service, $46(15.3 \%)$ disagree, while 10 (3.3) of the respondents were undecided. On the second item, question 10, 232 (77.3\%) of the respondent agree, 68 (22.6\%) disagree. The third item on the sub-scale, 185 (61.7\%) respondents agree that organizational knowledge can be transferred to employees, 90 (29.9\%) disagree, while 25 (8.3\%) of the total respondents were undecided. On the fourth construct in the sub-scale, 253 (84.4\%) agree, 20 (6.6\%) of the respondents disagree, while 27 (9) where undecided. The same high agreement rate was recorded for question 5 in Table 4.2.

Table 5 Knowledge Application

\begin{tabular}{|l|l|l|l|l|l|l|l|l|l|l|l|}
\hline S/N & Questionnaire Items & U (1) & \multicolumn{2}{l|}{ SD (2) } & D (3) & \multicolumn{2}{l|}{ A (4) } & SA (5) \\
\hline 1 & & Nos. & $\%$ & Nos. & $\%$ & Nos. & \% & Nos. & $\%$ & Nos. & $\%$ \\
\hline & $\begin{array}{l}\text { Allows for the application of } \\
\text { knowledge learned from } \\
\text { mistakes and experiences }\end{array}$ & 10 & 3.3 & 27 & 9 & 18 & 6 & 156 & 52 & 89 & 29.7 \\
\hline 2 & $\begin{array}{l}\text { Knowledge is applied to } \\
\text { solve new problems }\end{array}$ & - & - & 29 & 9.7 & 39 & 13 & 88 & 29.3 & 144 & 48 \\
\hline 3 & $\begin{array}{l}\text { Knowledge is made available } \\
\text { to those who need it. }\end{array}$ & 26 & 8.7 & 39 & 13 & 39 & 13 & 50 & 16.7 & 146 & 48.7 \\
\hline 4 & $\begin{array}{l}\text { Availability of Knowledge } \\
\text { can be used to develop new } \\
\text { product or service }\end{array}$ & 10 & 3.3 & 27 & 9 & 19 & 6.3 & 155 & 51.7 & 89 & 29.7 \\
\hline 5 & $\begin{array}{l}\text { Use knowledge to improve } \\
\text { efficiency. }\end{array}$ & 20 & 6.7 & 12 & 4 & 39 & 13 & 117 & 39 & 111 & 37 \\
\hline
\end{tabular}

Source: Analysis of Field Survey, 2019

The descriptive pattern of response in Table 4.4 for organizational work systems sub-scale indicated that on the first questionnaire item, 245 (81.7\%) of the respondents agree to the construct (Spacious office with modern facilities enhances productivity) and 45 (15\%) 
disagree and 10 (3.3) were undecided. On the third item on the sub-scale, 196 (65.4\%) respondents agree, 78 (26\%) disagree, while 10 (3.3\%) of the total sample respondents undecided. On the fourth construct in the sub-scale, 211 (70.3\%) agree that availability of Knowledge can be used to develop new product or service, 19 (2.3\%), while 20 (6.7) where undecided. With regards to the fifth question, 262 (87.3\%) of the respondents agree that their organization used knowledge to improve efficiency, 29 (9.7) disagree to the question.

Table 6 Knowledge Protection

\begin{tabular}{|c|c|c|c|c|c|c|c|c|c|c|c|}
\hline $\mathrm{S} / \mathrm{N}$ & Questionnaire Items & \multicolumn{2}{|c|}{$\mathrm{U}(1)$} & \multicolumn{2}{|c|}{ SD (2) } & \multicolumn{2}{|c|}{$\mathrm{D}(3)$} & \multicolumn{2}{|c|}{$\mathrm{A}(4)$} & \multicolumn{2}{|c|}{ SA (5) } \\
\hline & & No & $\%$ & No & $\%$ & No & $\%$ & No & $\%$ & No & $\%$ \\
\hline 1 & $\begin{array}{l}\text { Knowledge leakage can be } \\
\text { protected both inside and outside } \\
\text { the organization }\end{array}$ & - & - & 9 & 3 & 29 & 9.7 & 174 & 58 & 88 & 29.3 \\
\hline 2 & $\begin{array}{l}\text { Designs incentives that will } \\
\text { encourage the protection of } \\
\text { knowledge }\end{array}$ & - & - & 29 & 9.7 & 39 & 13 & 144 & 48 & 88 & 29.3 \\
\hline 3 & $\begin{array}{l}\text { Provides technology that can } \\
\text { restrict easy access to some } \\
\text { source of knowledge. }\end{array}$ & 26 & 8.7 & 48 & 16 & 41 & 13.6 & 39 & 13 & 146 & 48.7 \\
\hline 4 & $\begin{array}{c}\text { Blocks knowledge from theft } \\
\text { within or outside the organization }\end{array}$ & 10 & 3.3 & 27 & 9 & 19 & 6.3 & 155 & 51.7 & 89 & 29.7 \\
\hline 5 & $\begin{array}{l}\text { Detection of leakage of } \\
\text { knowledge by employees is } \\
\text { rewarded }\end{array}$ & - & - & 40 & 13.4 & 49 & 16.3 & 94 & 31.3 & 117 & 39 \\
\hline
\end{tabular}

Source: Analysis of Field Survey, 2019.

The descriptive pattern of response in Table 4.5 for employee's compensation and benefit sub-scale indicated that on the first questionnaire item, 232 (77.3\%) of the respondents strongly agree to the construct (Compensation is strategic to be organization goal and should be able to enhance employees satisfaction) and 68 (22.7\%) disagree. On the second item, 185 (61.7\%) respondent agree that because of strong relationship between, the components of compensation packages, performance are affected positively, which is a strong predictor of employees retention, 89 (29.6\%) disagree and 26 (8.7\%) were undecided. On the third item, on the sub-scale, 244 (81.4\%) respondents agree, 46 (15.3\%) disagree, while 10(3.3\%) of the total sample respondents undecided. On the fourth construct in the sub-scale, 211 (70.3\%) agree, 19 (2.3\%), while 20 (6.7) where undecided.

Table 7 Performance

\begin{tabular}{|c|c|c|c|c|c|c|c|c|c|c|c|}
\hline S/N & Questionnaire Items & \multicolumn{2}{|c|}{$\mathrm{U}(1)$} & \multicolumn{2}{|c|}{ SD (2) } & \multicolumn{2}{|c|}{$\mathrm{D}(3)$} & \multicolumn{2}{|c|}{$\mathrm{A}(4)$} & \multicolumn{2}{c|}{ SA (5) } \\
\hline & & No & $\%$ & No & $\%$ & No & $\%$ & No & $\%$ & No & $\%$ \\
\hline 1 & $\begin{array}{c}\text { Progressively, my organization has } \\
\text { increased its marketing effort }\end{array}$ & - & - & - & - & 25 & 8.3 & 129 & 43 & 146 & 48.7 \\
\hline 2 & $\begin{array}{c}\text { There is better risk management in } \\
\text { my organization }\end{array}$ & - & - & 29 & 9.7 & 39 & 13 & 144 & 48 & 88 & 29.3 \\
\hline 3 & $\begin{array}{c}\text { There is increase in market share } \\
\text { by percentage point, thereby } \\
\text { increasing profitability }\end{array}$ & 26 & 8.7 & 48 & 16 & 41 & 13.6 & 39 & 13 & 146 & 48.7 \\
\hline 4 & $\begin{array}{c}\text { There is reduction in } \\
\text { administrative costs. }\end{array}$ & 10 & 3.3 & 27 & 9 & 19 & 6.3 & 155 & 51.7 & 89 & 29.7 \\
\hline
\end{tabular}




\begin{tabular}{|c|c|c|c|c|c|c|c|c|c|c|c|}
\hline 5 & $\begin{array}{c}\text { My organization has the ability to } \\
\text { provide quality service to } \\
\text { customers }\end{array}$ & 20 & 6.7 & 20 & 6.7 & 49 & 16.3 & 117 & 39 & 94 & 31.3 \\
\hline
\end{tabular}

Source: Analysis of Field Survey, 2019

The descriptive pattern of response in Table 4.6 for performance sub-scale indicated that on the first questionnaire item, 275 (91.7\%) of the respondents strongly disagree to the construct (Progressively, my organization has increased its marketing effort) and 25 (8.3\%) disagree. On the second item on the sub-scale, 232 (77.3\%) respondent disagree, 68 (22.8\%) disagree. On the third item on the sub-scale, 185 (68\%) respondents disagree, 46 (15.3\%) disagree. On the fourth construct in the sub-scale, 211 (70.3\%) agree, 19 (2.3\%), while 20 (6.7) where undecided. With regards to the fifth question, 262 (87.3\%) of the respondents disagree, 29 (9.7) disagree to the question. 235 (78.4\%) of the respondents agree 59 (19.7\%) disagree while 6 (2\%) were undecided about the question. The same high agreement rate was recorded for question 4 and 5 as shown in Table 4.6.

Table 8 Descriptive Statistic

\begin{tabular}{r|rrrrrr} 
variable & mean & p50 & max & min & sd & N \\
- kacqn & 3.793333 & 4 & 5 & 1 & .9202055 & 300 \\
kconv & 3.846667 & 4 & 5 & 1 & .9161258 & 300 \\
kapp1 & 3.88 & 4 & 5 & 1 & .8334158 & 300 \\
kprot & 4.07 & 4 & 5 & 1 & .91719 & 300 \\
ogpef & 3.93 & 4 & 5 & 1 & .8450723 & 300 \\
\hline
\end{tabular}

Table 4.7 shows the descriptive properties of the data set used for the analysis, the constructs has a maximum value of 5 indicating that the respondents strongly agree at some point for all the questions asked, while the minimum of 1 for all the constructs. On the average the respondent chooses 4 (Disagree). The descriptive statistics Table further shows that the sample size of 300 respondents were sampled $(n=300)$

Table 9 Normality Test

\begin{tabular}{|c|c|c|c|c|c|}
\hline variable I & Obs & $\operatorname{Pr}$ (skewness) & $\operatorname{Pr}$ (Kurtosis) & adj chi2(2) & Prob $>$ chi 2 \\
\hline $\begin{array}{l}\text { kacqn } \\
\text { kconv } \\
\text { kapp1 } \\
\text { kprot } \\
\text { ogpef }\end{array}$ & $\begin{array}{l}300 \\
300 \\
300 \\
300 \\
300\end{array}$ & $\begin{array}{l}0.0000 \\
0.0000 \\
0.0000 \\
0.0000 \\
0.0000\end{array}$ & $\begin{array}{l}0.3819 \\
0.0007 \\
0.0007 \\
0.2271 \\
0.0007\end{array}$ & $\begin{array}{l}22.06 \\
45.07 \\
42.28 \\
26.71 \\
42.67\end{array}$ & $\begin{array}{l}0.0000 \\
0.0000 \\
0.0000 \\
0.0000 \\
0.0000\end{array}$ \\
\hline
\end{tabular}

Source: Researcher's computation (using stat. version 13.0)

The result of Jacque Bera normality test was showed in Table 4.8; shows that all the variables are normally distributed at 5\% level of significance. Hence, any recommendations made to a very large extent would represent the characteristics of the through population of the study. 
Correlations among the variables of knowledge management dimensions and employees' performance

\begin{tabular}{l|llllr} 
& kacqn & kconv & kappl & kprot & ogpef \\
\hline kacqn & 1.0000 & & & & \\
kconv & 0.3511 & 1.0000 & & & \\
kapp1 & 0.5083 & 0.4314 & 1.0000 & & \\
kprot & 0.4888 & 0.5621 & 0.5929 & 1.0000 & \\
ogpef & 0.3469 & 0.4224 & 0.3632 & 0.4594 & 1.0000
\end{tabular}

Correlation is significant at the 0.05 level (2-tailed)

Source: Researcher's computation (using stat. version 13.0)

The result in Table 4.9 reveals that there is positive correlation involving the dimensions of knowledge management and organizational performance. The result shows a positive correlation among the variables under study ranging from 0.3469 low to 0.5929 high.

\section{Test of Hypotheses}

\section{Decision Rule}

The null hypothesis shall be accepted if the p-value (calculated value) is greater than $(>)$ the established level of significance (critical value) and we are to reject the null hypothesis if otherwise (less than $(<)$ the critical value). The level of significance that is above 0.05 is a condition for accepting the null hypothesis (Ho). But if otherwise, that is p-value less than 0.05 is the condition for rejecting the null hypothesis (Ho) (Gujarati \& porter, 2009).

Post Regression Diagnostic Test (PRDT)

Post regression test was performed after the regression analysis to certify the regression model before testing for the formulated hypotheses.

Table 10 Test for Variance Inflation Factor

\begin{tabular}{rrr} 
Variable | & VIF & $1 /$ VIF \\
\hline kprot & 1.97 & 0.506797 \\
kappl & 1.73 & 0.577110 \\
kconv & 1.50 & 0.666483 \\
kacqn & 1.46 & 0.684684 \\
\hline Mean VIF & 1.67 &
\end{tabular}

VIF must be less than 10. (Marks, Philip \& Adrea, 2009)

Source: Researcher's computation

The result in Table 4.10 shows the test for variance inflation factor test; the mean VIF value is 1.67 which is less than the benchmark value of 10 indicates the absence of multicolinearity. Hence, we go ahead to test for the hypotheses.

\section{Ramsey Regression Equation Specification Error Test (RESET)}

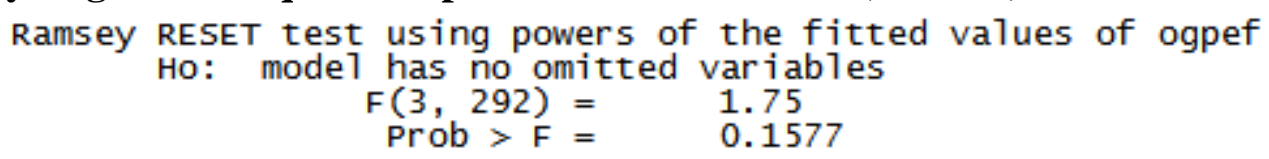

Source: Researcher's computation 
Table 4.11 shows the results obtained from the test for Ramsey regression equation specification error test, the probability value of 0.1577 means that the model has no omitted variables.

Table 11 Test for Heteroskedasticity

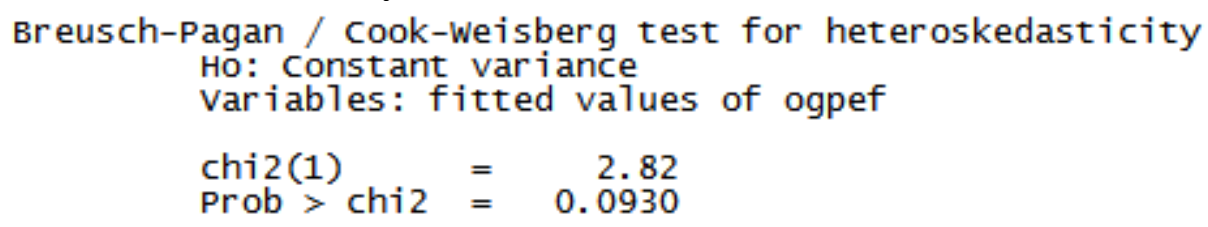

Source: Researcher's computation (using stat. version 13.0)

The result in Table 4.12 for the test for heteroskedasticity, shows that the variation between the dependent and independent variables are hemoskedastic implying that there is no heteroskedasticity problem (2.82(0.0930)). This means that, the model is free from presence of unequal variance. This further indicates that our probability values for drawing inference on the level of significant are reliable and valid. Thus, validating the OLS results and implying we should go ahead and test the hypotheses and that there is no need for robust regression. Hence, the regression results can be used to test the formulated hypotheses.

H1: Knowledge acquisition does not have significant effects on the Organizational performance of deposit money banks in Nigeria.

Table 12 OLS Regression Result of Knowledge acquisition (Independent Variable) and Organizational performance (Dependent Variable)

\begin{tabular}{|c|c|c|c|c|}
\hline Variables. & B & Std. Err. & T & P $>/ t /$ \\
\hline Knowledge Acquisition & .3185792 & .0498951 & 6.38 & 0.000 \\
\hline Cons. & 2.721523 & .1947401 & 13.98 & 0.000 \\
\hline R-squared & \multicolumn{3}{|c|}{0.1203} \\
\hline Adj. R-squared: & \multicolumn{3}{|c|}{0.1174} \\
\hline F & \multicolumn{3}{|c|}{0.0000 .77} \\
\hline Prob.>F. & \multicolumn{3}{|c|}{} \\
\hline
\end{tabular}

Source: Researcher's computation (using Stat, version 13.0 see Results in appendix 2)

The regression result output shows that Knowledge acquisition has a significant positive effect on organizational performance with $(\beta=0.3185(0.000))$. Generally the p-value of Knowledge acquisition is less than $(p=0.000)$ is less than 0.05 ; hence, we reject the null hypothesis and accept the alternate, which state that Knowledge acquisition has significant positive relationship with performance. The F-statistic value of 40.77 and its associated Pvalue of 0.000 shows that the regression model on the overall is statistically significant at $1 \%$ level, this means that the regression model is valid. Hence:

$$
\text { Model 1: OGPEF }=2.721+0.318 \mathrm{KACQN}+\mathrm{U}
$$


As indicated in Table 4.13, Adj. R-Squared of the models is 0.117 implying that $11.7 \%$ change in the dependent variable (organizational performance) on the overall is brought about by the independent variable (knowledge acquisition)

H2: $\quad$ There is no significant relationship between knowledge conversion and the organizational performance of deposit money banks in Nigeria.

Table 13 OLS Regression Result of knowledge conversion (Independent Variable) and Organizational performance (Dependent Variable)

\begin{tabular}{|c|c|c|c|c|}
\hline Variables. & B & Std. Err. & $\mathrm{T}$ & $\mathrm{P}>/ \mathrm{t} / \mathrm{0}$ \\
\hline Knowledge conversion & .3896445 & .0484344 & 8.04 & 0.000 \\
\hline Cons. & 2.431167 & .1915048 & 12.70 & 0.000 \\
\hline R-squared & \multicolumn{3}{|c|}{0.1784} \\
\hline Adj. R-squared: & \multicolumn{3}{|c|}{0.1757} \\
\hline F & \multicolumn{3}{|c|}{0.0000.} \\
\hline Prob.>F. & \multicolumn{3}{|c|}{} \\
\hline
\end{tabular}

Source: Researcher's computation (using Stat. version 13.0 see Results in appendix 2)

The regression result output in table 4.14 shows that knowledge conversion has a significant positive effect on organizational performance with $(\beta=0.389(0.000))$. Generally the $p$-value of knowledge conversion is less than $(p=0.000)$ is less than 0.05 ; hence, we reject the null hypothesis and accept the alternate, which state that knowledge conversion has significant positive relationship with organizational performance. The Fstatistic value of 64.72 and its associated $\mathrm{P}$-value of 0.000 shows that the regression model on the overall is statistically significant at $1 \%$ level, this means that the regression model is valid. Hence:

Model 2: OGPEF $=2.431+0.389 \mathrm{KCONV}+\mathrm{U}$

As indicated in Table 4.14, Adj. R-Squared of the models is 0.175 implying that $17.5 \%$ change in the dependent variable (organizational performance) on the overall is brought about by the independent variable (knowledge conversion).

H3: There is no significant relationship between knowledge application and the organizational performance of deposit money banks in Nigeria.

Table 14 OLS Regression Result of knowledge application (Independent Variable) and Organizational performance (Dependent Variable)

\begin{tabular}{|c|c|c|c|c|}
\hline Variables. & B & Std. Err. & $\mathrm{T}$ & $\mathrm{P}>/ \mathrm{t} /$ \\
\hline knowledge Application & .3682589 & .0547279 & 6.73 & 0.000 \\
\hline Cons. & 2.501156 & .2171718 & 11.52 & 0.000 \\
\hline R-squared & \multicolumn{3}{|c|}{0.1319} \\
\hline Adj. R-squared: & \multicolumn{3}{|c|}{0.1290} \\
\hline F & \multicolumn{3}{|c|}{45.28} \\
\hline
\end{tabular}




\begin{tabular}{|c|c|}
\hline Prob.>F. & 0.0000. \\
\hline
\end{tabular}

Source: Researcher’s computation (using Stata version 13.0 see Results in appendix 2)

The regression result output in table 4.15: shows that knowledge application has a significant positive effect on organizational performance with $(\beta=0.368(0.000))$. Generally the $\mathrm{p}$-value of knowledge application is less than $(\mathrm{p}=0.000)$ is less than 0.05 ; hence, we reject the null hypothesis and accept the alternate, which state that knowledge application has significant relationship with organizational performance. The F-statistic value of 45.28 and its associated P-value of 0.000 shows that the regression model on the overall is statistically significant at $1 \%$ level, this means that the regression model is valid. Hence:

$$
\text { Model 3: OGPEF }=2.501+0.368 \mathrm{KAPPL}+\square
$$

As indicated, Adj. R-Squared of the models is 0.129 implying that $12.9 \%$ change in the dependent variable (organizational performance) on the overall is brought about by the independent variable (knowledge application)

H4: There is no significant relationship between knowledge protection and organizational performance of deposit money banks in Nigeria.

Table 15 OLS Regression Result of knowledge protection (Independent Variable) and Organizational performance (Dependent Variable)

\begin{tabular}{|c|c|c|c|c|}
\hline Variables. & B & Std. Err. & $\mathrm{T}$ & $\mathrm{P}>/ \mathrm{t} / \mathrm{0}$ \\
\hline knowledge Protection & .4232895 & .0474076 & 8.93 & 0.000 \\
\hline Cons. & 2.207212 & .1977719 & 11.16 & 0.000 \\
\hline R-squared & \multicolumn{3}{|c|}{0.2111} \\
\hline Adj. R-squared: & \multicolumn{3}{|c|}{0.2084} \\
\hline F & \multicolumn{3}{|c|}{0.0000.} \\
\hline Prob.>F. & \multicolumn{3}{|c|}{} \\
\hline
\end{tabular}

Source: Researcher's computation (using Stata version 13.0 see Results in appendix 2)

The regression result output in table 4.16 shows that knowledge protection has a significant positive effect on organizational performance with $(\beta=0.423(0.000))$. Generally the $p-$ value of knowledge protection $(\mathrm{p}=0.000)$ is less than 0.05 ; hence, we reject the null hypothesis and accept the alternate, which state that knowledge protection has significant positive relationship with organizational performance. The F-statistic value of 79.72 and its associated P-value of 0.000 shows that the regression model on the overall is statistically significant at $1 \%$ level, this means that the regression model is valid. Hence:

$$
\text { Model 4: OGPEF } \quad=2.207+0.423 \mathrm{KPROT}+\square
$$

As indicated in Table 4.16, Adj. R-Squared of the models is 0.208 implying that $20.8 \%$ change in the dependent variable (organizational performance) on the overall is brought about by the independent variable (knowledge protection).

Justification for Small r2 
The reported r2 calls for mediating variables, or moderating / intervening variables. Gold et al. (2001) stressed that the presence of knowledge management infrastructure (cultural, structural and technological knowledge management infrastructure) will facilitate the activities of knowledge management practices. Hence further studies should include these infrastructures to improve the r2 value or including them as control variables. Moreso, there are many dimensions of knowledge management but the present study only considered four dimensions leaving the rest unexplored.

\section{Discussion of Results}

The regression result output shows that Knowledge acquisition has a significant positive effect on organizational performance with $(\beta=0.3185(0.000))$. Generally the $p$ value of Knowledge acquisition is less than $(p=0.000)$ is less than 0.05 ; hence, we reject the null hypothesis and accept the alternate, which state that Knowledge acquisition has significant positive relationship with performance. This is in consonance with the findings of (Martin, 2012; Valmohammadi \& Ahmadi, 2015; Nnabufe, Onwuka \& Ojukwu, 2015; Akpotu \& Lebari, 2014; Popov \& Vlasov, 2014; Felis, 2017, Salman, 2017; Gangaram, 2018; Eric-Nielsen \& Aleksandra, 2018) that knowledge acquisition has a significant effect on organizational performance. The regression result output in table 4.14 shows that knowledge conversion has a significant positive effect on organizational performance with $(\beta=0.389(0.000))$. Generally the $p$-value of knowledge conversion is less than $(p=0.000)$ is less than 0.05; hence, we reject the null hypothesis and accept the alternate, which state that knowledge conversion has significant positive relationship with organizational performance. This finding aligned with (Mahammad, Mehhred, Salma \& Nurizy, 2013: Adbsel, Gawater \& Mohamad, 2012; Felix, 2017; Akram \& Hilman, 2018; Onyango, 2018) that knowledge management dimensions has a significant positive effect on organizational performance. Moreso, Godfrey, Stephen and James (2015) supported the view that knowledge creation promotes organizational performance.

The regression result output in table 4.15: shows that knowledge application has a significant positive effect on organizational performance with $(\beta=0.368(0.000))$. Generally the $p$-value of knowledge application is less than $(p=0.000)$ is less than 0.05 ; hence, we reject the null hypothesis and accept the alternate, which state that knowledge application has significant relationship with organizational performance. The finding is in consonant with (Miguel, Saavedra \& Lindemann, 2016; Hayfa \& Abdullah, 2018; Akram \& Hilman, 2018; Onyango, 2018; Aygul \& Bahtisen, 2017) that knowledge application has significant relationship with organizational performance. This is further supported by (Seyed, 2015) that information management and intelligence gathering are relevant to knowledge application.

The regression result output in table 4.16 shows that knowledge protection has a significant positive effect on organizational performance with $(\beta=0.423(0.000))$. Generally the $p$-value of knowledge protection $(p=0.000)$ is less than 0.05 ; hence, we reject the null hypothesis and accept the alternate, which state that knowledge protection has significant positive relationship with organizational performance. This is in accord with (Keren Elliot, Andrea, Joes \& Walter Julian, 2016: Stefan \& Markus, 2015; Hayfa \& Abdullah, 2018; Onyango, 2018; Lekhanath, 2017) that protecting knowledge leads to competitive advantage which results to optimum performance. They recommended that 
information should be protected to ensure and enhance competitive advantage. That information should not be lost through employees trust worthiness.

\section{Conclusion}

In a knowledge driven economy, deposit money banks that manage and sustain knowledge are always very successful. Better still; companies that are using their knowledge in right way, and managing it effectively to their gain in terms of strategy that is significant to the organization could be more successful. Identifying and leveraging the individual and collective knowledge in an organization to support the organization in becoming more competitive is the essence of knowledge management. Because employees in the workplace are drivers, their knowledge should be managed and pooled together so that the organization can use it to build unique knowledge to enhance the organization's activities. Knowledge management has assumed an important dimension in organizations today because the major competitive advantage for an organization lies in the corporate knowledge. This implies that for organizations to prosper, they have to treat knowledge well since it contributes to their core competencies, just as they would do to any other strategic, irreplaceable assets. Knowledge management is concerned with the entire process of discovering and creation of knowledge, dissemination of knowledge, the utilization of knowledge and protection of knowledge.

The goal of knowledge management is for an organization to become aware of its knowledge both individually and collectively. Knowledge provides superior offerings which are given to customers for value. Value cannot be offered without some competencies by organizations. Competencies are brought about by organization's knowledge. The knowledge gives a competitive advantage if properly managed by organizations. Knowledge management yields competitive advantage giving an edge to a business beyond what the competition has and does. Competitive advantage represents a threat to competitors and weakens the effort of rival organizations. Effective knowledge management practice will help organizations gain competitive advantage and improve performance in the business environment, beyond that, its marketing effort will also go up and better risk management in the organization, reduction in administrative costs, provide quality service to customers in the organization and this will help in achieving higher customers satisfaction and deposit money banks will able to solve the persisting problems in the sector.

\section{Recommendations}

In the light of the findings of this study, the following recommendations were made. Deposit money banks should encourage knowledge conversion practices so that their performances will improve. This means that as a group of people having common identity, professional interest to undertake share, participate and establish a fellowship in their line of trade, their interaction with one another will improve the use of information and communication techniques to enrich their knowledge and expertise for proper development in their banking operations.

Banks should ensure the protection of their acquired knowledge within the organization so as to gain better performance. Knowledge protection is required to ensure the promotion of competitive advantage in their operation. Banks should come up with 
policies that will encourage knowledge management practices in other to improve their performance through their organizational learning and training on the part of employees. This is necessary to influence employee to participate in knowledge management activities. Their competencies will provide for steering the change effort and convey the importance of knowledge management to employees.

Appropriate technological infrastructure should be provided to facilitate knowledge storing and knowledge protection within the firm. Deposit money banks should be IT driven. This is necessary in the area of information systems and other related terms. Its capability has evolved key enablers for implementing knowledge management through its information technology as a connector of human to information and of one human to another. IT provides for rapid search, access and retriever of information and can support collaboration and communication between organizational members.

\section{Contributions to Knowledge}

As a result of the outcome of the research, the following novel/unique contributions to knowledge:

- The study affirmed that knowledge acquisition facilitate organizational performance through its improved marketing effort.

- The study indicated that knowledge conversion enhances organizational performance in the areas of expertise and efficiency in the conduct of business.

- The knowledge application enhances organizational performance in the area of better risk management to minimize losses.

- Knowledge protection showed knowledge required security so as to achieve competitive advantage towards better quality service delivery to customers against competitors.

- Knowledge management and organizational performance of deposit money banks demonstrated a hybrid of resource-based theory and the left brain and right brain management theory.

\section{Suggested areas for further Study}

The present study is centered on knowledge management and organizational performance in selected Banks in Nigerian using a sample size of three hundred (300). Future studies should expand the sample size to accommodate more Bankers in Nigeria and the manufacturing sector as well.

The present study made use of four (4) dimensions of knowledge management practices, without any dimension of knowledge management infrastructure, no control variable or moderating variable, future studies should include dimensions of knowledge management such as knowledge sharing, knowledge storing along with other knowledge management infrastructures and mediating variables.

\section{References}

1. Ababneh, R.I. (2008). The impact of knowledge management and organizational learning on organization innovation: in proceedings of knowledge management international conference on Transferring, 
managing, maintaining knowledge for national capacity development. Knowledge Management Journal, 1(1), 601-609. http://www.kmice.cms.net.my/

2. Ababneh, R.I. (2008). The impact of knowledge management and organizational learning on organizational innovation: In proceedings of knowledge management. International Conference on Transferring, Managing, Maintaining Knowledge for National Capacity Development, $1(1), 609$ http://www.kmice.cms.net.my/

3. Abdel, G. \& Mohamad (2012). The role of knowledge management in enhancing organizational performance in information engineering and electronic engineering. Business Journal, 5(6), 27 - 28. https://doi.org/10.5815/ijieeb.2012.05.04

4. Andries, A.M. and Asandului, M., 2010. The impact of financial liberalization on the performance of banks in Romania. Metalurgia International, 15(11), pp.97-106.

5. Bosua, R. \& Venkitachalam, K. (2013).Aligning strategies and processes in knowledge management: A framework. Journal of Knowledge Management, 17(3), $331 \quad$ - 346. https://doi.org/10.1108/JKM-10-2012-0323

6. Bounfour, A. (2005). The management of intangibles: the organization's most valuable assets, 16(1), 1-15.

7. Caldas, P.T. \& Candido, G.A. (2013).Inter-organizational knowledge conversion and innovation capacity in co-operative networks. Journal of technology Management and Innovation, 8(1), 104 - 114. $\underline{\text { https://doi.org/10.4324/9780203465035 }}$

8. Chen, C.J. (2005). The effect of knowledge attribute, alliance characteristics and absorptive capacity on knowledge transfer performance. R\&D Management, 34(3), 311-324. https://doi.org/10.1111/j.14679310.2004.00341.x

9. Chillon, M.A. \&Bloodgood (2010). Adaption - innovation theory and knowledge use in

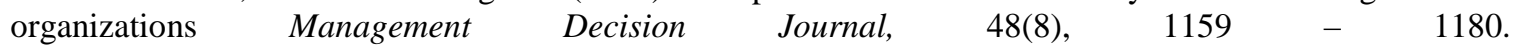
https://doi.org/10.1108/00251741011076726

10. Darrock, J. (2005). Knowledge management, innovation and firm performance.Journal of Knowledge Management, 9(3), 101 - 115. https://doi.org/10.1108/13673270510602809

11. Epetimehin, F.M. \& Ekundayo, O. (2011). Organizational knowledge management: survival strategy for Nigeria insurance industry. Interdisciplinary Review of Economics and Management, 1(2), 9 15.

12. Ethiotok, A. J. \& Walter, J. (2016).The effects of knowledge management practices on firm performance. Journal Knowledge $\quad$ Management, $\quad 10(3), \quad 143 \quad-\quad 156$. https://doi.org/10.1108/13673270610670911

13. Fugate, B.S., Stank, T.P. \& Mentzer, J.T. (2009). Linking improved knowledge management to operational and organizational and organizational performance. Journal of Operational Management, 27(2), 247 - 264, http://dx.doi.org/10.1016/10m 200809003.

14. Gangaram, B. (2018). Knowledge management and employee job performance in Nepalese banking sector. International Journal of Research in Business Studies and Management, 5(3), 15 - 23.

15. Gao, F., Li, M. \& Nakamori, Y. (2008). Critical systems thinking as a way to manage knowledge. Systems Research Behavioural Science Journal, 1(11), 10 - 30. https://doi.org/10.1002/sres.512

16. Godfrey, M.K. \& Stephen, M.A.M. (2015).Effect of knowledge conversion and knowledge applications on performance of Money Deposit Banks in Kenya.International Journal of Education and Research, 3(10), $431-444$.

17. Hankanson, L. (2010). The firm as an Epistemic Community: Knowledge based view revisited. Industrial and Corporate Change, 19(6), 18-28. https://doi.org/10.1093/icc/dtq052

18. Hayfa, Y.A. \& Abdullah, A.M.A. (2018).The impact of knowledge management on organizational performance. International Journal of Advanced Computer Science and Application, 9(4), 204 - 208.

19. Holsapple, C.W. \& Wu, J. (2011).An elusive antecedent of superior firm performance.The knowledge management factors. Decision Support Systems, 52(1), 271-283. https://doi.org/10.1016/j.dss.2011.08.003
20 . Kaplan, R.S. \& Norton, D.P. (1996).How to implement a new strategy without ampting your organization. Harvard Business Review, 1(2), 100-109.

21. Karuoya, K. \& Thomas (2017). Knowledge management and the occasional links with performance. Journal of Knowledge Management, 7(3), 67 - 81. https://doi.org/10.1108/13673270310485631 
22. Kimaiyo, I.K., Kapkiyai, C. \& Sang (2015). Effect of knowledge management on firm performance in commercial banks in Nakuru Eldoret and Kisumu. European Journal of Business and Management, 7(3), $209-216$.

23. Kuo, T.H. (2011). How to improve organizational through learning and knowledge. International Journal of Manpower, 32(5/6), 581 - 603. https://doi.org/10.1108/01437721111158215

24. Lee \& Choi (2006). Knowledge management enablers, processes and organizational performance: an integrative view and empirical examination. Journal of Management Information Systems, 20(1), 179228. https://doi.org/10.1080/07421222.2003.11045756

25. Lupu, D. (2019). Financial development and economic growth in Eastern Europe. Journal of Public Administration, Finance and Law, (16), 157-165.

26. Moffet \& Hinds (2010).Fostering knowledge sharing through human resources management in $\mathrm{R}$ and D teams. International Journal of Technology Management, 53(2 - 4), 309 - 330.

27. Nonaka, I. \& Krogh, S. (2009). Tacit knowledge and knowledge conversion, controversy and advancement in organizational knowledge creation theory. Perspective Organizational Science, 20(3), 635 652. https://doi.org/10.1287/orsc.1080.0412

28. Noruzy, A., Dalfard, V., Azhdari, B., Nazari-Shirkouchi, S. \& Reyazadeh, A.S. (2013). Relations between transformational leadership organizational learning, knowledge management organization innovation and organizational performance: An empirical investigation of manufacturing firms International. Journal of Advanced Manufacturing Technology, 64(5-8), 1073-1085. https://doi.org/10.1007/s00170-012$\underline{4038-\mathrm{y}}$

29 Oluikpe, P (2012). Developing a corporate knowledge management strategy. Journal of Knowledge Management, 16(6), 862 - 878. https://doi.org/10.1108/13673271211276164

30. OU, Yang, L. (2014). Cyclic Model for knowledge management capability. A review study Arab Journal of Business Management Performance, 4(4), 1-9. http://dx.doi.org/10.4172/2223-5833.1000118

31. Pension, K., Nuasha, M., Schiller, M. \& Vhuramai (2013). Impact of knowledge management on organizational performance: A case study of Grain marketing board Greener. Journal of Business and Management Studies, 3(6), 170 - 278.

32. Pierre, J., Timothy, D. \& George, S. G. (2010). Measuring organizational performance a dependent variable: Towards methodological Best Practices Knowledge management journal 2(1), 55-75.

33. Rasula, J. \& Stemberger, I.M. (2012).The impact of knowledge management on organizational performance. Economic and Business Review, 14(2), 147-168. https://doi.org/10.15458/2335-4216.1207

34. Richard, P., Davinney, S. \& George, J. (2009). Measuring organizational performance on a dependent variable: towards methodological best practices. Knowledge Management Journal, 2(1), 55 - 75. https://doi.org/10.1177/0149206308330560

35. Richard, P., Davinney, S. \& Johnson, G. (2009). Measuring organizational performance: towards methodological best practices. Journal of Management, 35(3), 718 - 804. https://doi.org/10.1177/0149206308330560

36. Richard, P., Devinney, S. \& George, J. (2009). Actions to overcome knowledge transfer barrier in MNCS. Journal of Knowledge Management, 11(1), 48-67. https://doi.org/10.1108/13673270710728231

37. Roy, S.K. \& Sivakumar, Y. (2011).Leveraging collaborative technologies to build knowledge sharing culture at hp analytics. MIS Quarter Executive, 10(1), 1-18 https://aisel.aisnet.org/misqe/vol10/iss1/5 38. Salisbury, M. \& Plass, J. (2001).A conceptual framework for a knowledge management system. Human Resources Development International, 13(3), 10 - 19. https://doi.org/10.1080/13678860010016913

39. Salman, B.M. \& Sumaiya, S. (2017). Organization of knowledge management in knowledge intensive Pakistani banks: a qualitative case study. Knowledge and Performance Management Journal, 1(1), $36-45$.

40. Sayed, H.S. (2015). Effective factors of successful implementation of knowledge management in higher education. Management and Administration Science Review, 4(1), 166 - 1811

41. Shih, K.H., Chang \& Lin, B. (2018). Assessing knowledge creation and intellectual capital in banking industry. Journal of Intellectual Capital, $11(1), \quad 74-89$. https://doi.org/10.1108/14691931011013343

42. Storey, J.\& Quintas, E. (2000). Knowledge management initiatives: learning from Failure Journal of Knowledge Management, 4(2), 50 - 62. https://doi.org/10.1108/13673270010372279

43. Thomas, J, W. \& Bizer, K. (2013).To protect or not to protect?Modes of appropriability in the small enterprise sector. Research Policy Journal, 42(1), 35 - 49. https://doi.org/10.1016/j.respol.2012.04.019 
44. Tseng, S. \& Lee, P. (2014). The effect of knowledge management processes on organizational performance. Journal of Enterprise Information Management, 27(2), 158 - 179. https://doi.org/10.1108/JEIM-05-2012-0025

45. Valmohammadi, C. \& Ahmadi, M. (2015). The impact of knowledge management practices on organizational performance: A balanced score card approach. Journal of Enterprise Information Management, 28(1), 131-159. https://doi.org/10.1108/JEIM-09-2013-0066

46. Wang, S., Noe, R. \& Wang, Z. (2016).Motivating knowledge sharing in knowledge management system: a quasi-field management. Journal of Management, 4(4), 978 - 1009. https://doi.org/10.1177/0149206311412192 Creative Commons Attribution - Non Commercial - No Derivatives 4.0 International License. 